\title{
Ancient DNA comes of age
}

AUTHOR:

Alan Morris

\section{AFFILIATION:}

'Department of Human Biology, University of Cape Town, Cape

Town, South Africa

\section{CORRESPONDENCE TO: \\ Alan Morris}

\section{EMAIL:}

alan.morris@uct.ac.za

\section{POSTAL ADDRESS:}

Department of Human Biology, Faculty of Health Sciences, University of Cape Town, Anzio Road, Observatory 7925, South Africa

\section{KEYWORDS:}

DNA extraction; genetic studies; South Africa

\section{HOW TO CITE:}

Morris AG. Ancient DNA comes of age. S Afr J Sci. 2015;111(5/6), Art. \#a0108, 2 pages. http://dx.doi. org/10.17159/sajs.2015/a0108

(C) 2015. The Author(s). Published under a Creative Commons Attribution Licence.
If you think about it, extracting DNA from bones of people long dead is an impressive achievement. The decomposition of soft tissue is a fairly quick (and smelly) process that generally takes about 2-3 months under normal South African summer weather conditions. Buried bone tends to lose its soft tissue components after a few years, becoming light and friable. Most archaeological bones have lost the integrity of their collagen matrix after a century or two, and structurally and microscopically well-preserved bone elements are fairly rare after a few thousand years. That is what makes it absolutely amazing that the detail of DNA can survive such long periods and can be recovered by scientists.

Our first attempt to extract ancient DNA from South African human skeletons was done by Alec Knight, then of Stanford University, and myself in 2002. We sampled 22 Later Stone Age skeletons ranging from 400 to about 6000 years old. Alec did the laboratory work back at Joanna Mountain's lab in California, but despite his meticulous efforts, the project was a complete failure. Not one ancient DNA sample was retrieved. Our frustration was extreme because other researchers had managed to extract DNA from the far more ancient bones of Neanderthals in Europe. ${ }^{1}$ We now know that we faced several problems which resulted in our failure. DNA was present in the samples, but it was extremely fragmentary and technically difficult to extract with the technology available then. DNA does not exactly 'decompose' with time. Rather it fragments into small sections. One of the calling cards of ancient DNA is fragments of less than 50 nucleotide base pairs in length.

Twelve years later I linked up with a different research group to try again. The University of Cape Town archaeologist Andy Smith had carefully taken bone samples from a newly excavated skeleton at St Helena Bay and sent samples to Vanessa Hayes in Sydney, Australia, for analysis. With vastly improved laboratory technology and better methods of sequencing the DNA fragments, we were able to obtain a complete mitochondrial sequence for the 2300-year-old skeleton from St Helena Bay. ${ }^{2}$ The St Helena Bay ancient mtDNA produced a new LOd2c lineage (LOd2c1c), most closely related to contemporary indigenous San speakers (specifically the Ju) in the northern Kalahari and unlike its sister clades (L0d2c1a and LOd2c1b) which were found amongst Khoe-language speakers. Although the results are intriguing, the fact is that this lineage from a single individual elicited more questions than it answered.

Essentially, the gates for ancient DNA research in southern Africa are now open. Already a substantial body of DNA knowledge for living Khoesan peoples is available, ${ }^{3-5}$ which gives us a tremendous capability for comparison. The race is on to extend this work back in time through ancient DNA. ${ }^{6,7}$ To my knowledge, there are now several projects in preparation, nearing completion, or already done. The analysis of specimens from the Later Stone Age and the Early Iron Age have produced some results for which there should be publications in the near future. Earlier specimens from the dawn of modern humanity 100000 years ago or more have also been sampled, but we shall have to wait to see if enough DNA can be extracted for analysis. Laboratories in Germany, Denmark, Sweden, Australia and the USA have been involved. This is truly a rush for knowledge in a new field. Amongst the studies is one which has looked at the genetics of the oral bacteria preserved in the dental tartar attached to the teeth of ancient specimens. So it is not only ancient humans we can analyse, but also the DNA of species that have co-evolved with us.

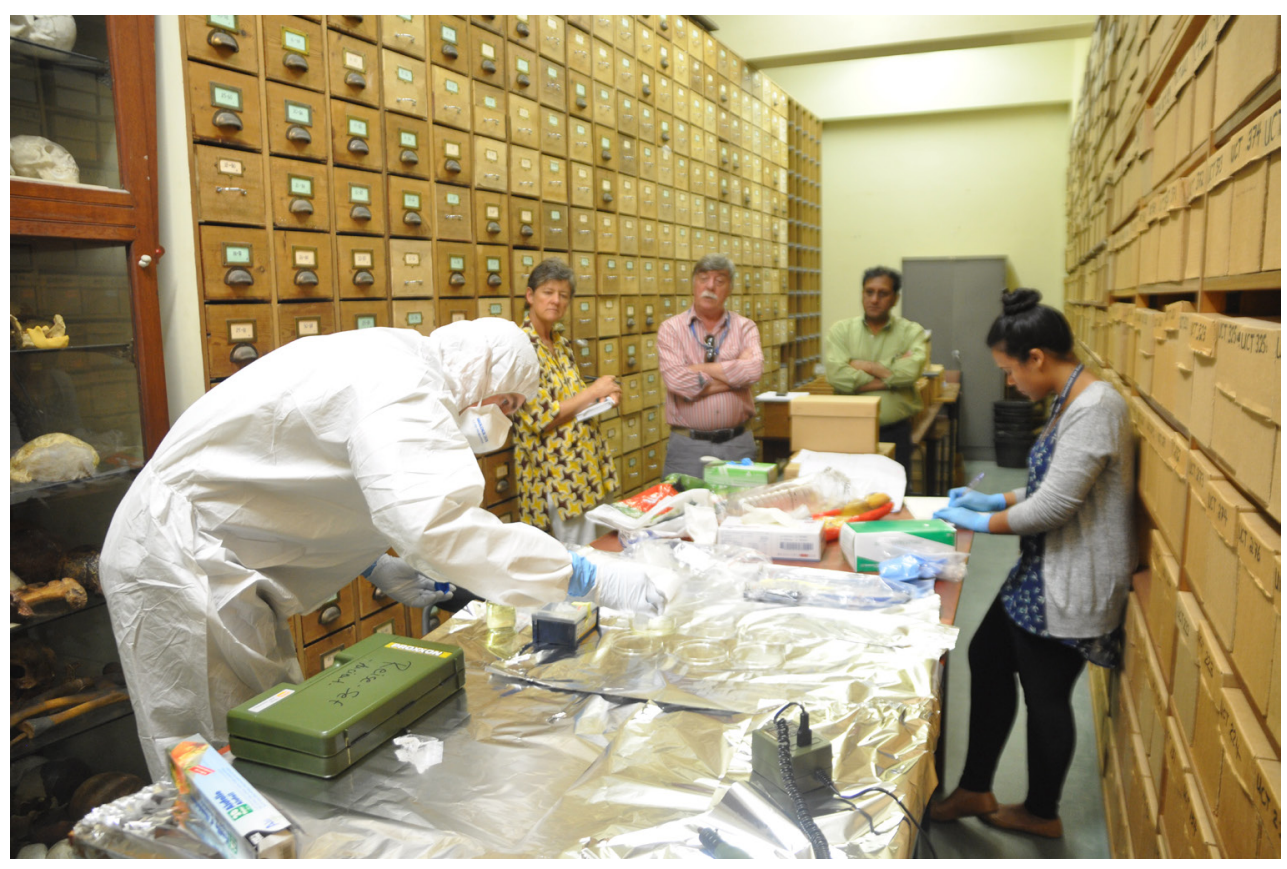

Johannes Krause of Tuebingen University and Tasneem Salie of the University of Cape Town (UCT) sample ancient DNA from Later Stone Age specimens in the Department of Human Biology's Osteology Laboratory at UCT. This project looks specifically at the 2000-year-old site of Farasokop near Vredendal in the Western Cape. Professors Nicola Illing (UCT Molecular \& Cell Biology), John Parkington (UCT Archaeology) and Raj Ramesar (UCT Human Genetics) look on. (Photo: Alan Morris) 
I remain intrigued by the information gleaned from a genetic study of human body lice done several years $\mathrm{ago}^{8}$ in which the lice tracked at least two separate human lineages from ancient times to now.

The technological advances that have enabled the study of ancient DNA in southern Africa have also expanded the range of genetic data available. The earlier work primarily focused on mitochondrial and Y-chromosome DNA lineages. These track female and male lines, respectively, back in time and give a good guide to the timing of population splits, but they are of relatively limited value in identifying specific relationships between individuals and miss large blocks of ancestry not represented in the surviving female or male lineages. The latest research has looked at nuclear autosomal DNA and has begun to provide data on admixture between populations and the impact of natural selection on specific genetic traits. ${ }^{9-12}$ The 'Holy Grail' in ancient DNA work is now to extract this nuclear information from long dead southern African individuals and even possibly to generate a complete genome for a representative individual. I suspect that a publication announcing this feat will not be too far in the future.

\section{References}

1. Krings M, Stone A, Schmitz RW, Krainitzki H, Stoneking M, Paabo S. Neandertal DNA sequences and the origin of modern humans. Cell. 1997;90:19-30. http://dx.doi.org/10.1016/S0092-8674(00)80310-4

2. Morris AG, Heinze A, Chan E, Smith AB, Hayes VM. First ancient mitochondrial human genome from a pre-pastoralist southern African. Genome Biol Evol. 2014;6(10):2647-2653. http://dx.doi.org/10.1093/gbe/evu202

3. Barbieri C, Vicente M, Oliveira S, Bostoen K, Rocha J, Stoneking M, et al. Migration and interaction in a contact zone: mtDNA variation among Bantuspeakers in southern Africa. PLoS ONE. 2014;9(6):e99117. http://dx.doi. org/10.1371/journal.pone.0099117
4. Schuster SC, Miller W, Ratan A, Tomsho LP, Giardine B, Kasson LR, et al. Complete Khoisan and Bantu genomes from southern Africa. Nature. 2010;463:943-947. http://dx.doi.org/10.1038/nature08795

5. Schlebusch CM, Skoglund P, Sjodin P, Gattepaille LM, Hernandez D, Jay F, et al. Genomic variation in seven Khoe-San groups reveals adaptation and complex African history. Science. 2012;338(6105):374-379. http://dx.doi.org/10.1126/ science. 1227721

6. Lombard M, Schlebusch C, Soodyall H. Bridging disciplines to better elucidate the evolution of early Homo sapiens in southern Africa. S Afr J Sci. 2013;109(11/12):27-34. http://dx.doi.org/10.1590/sajs.2013/20130065

7. Lombard M. Human DNA and Stone Age archaeology. The Digging Stick. 2014;31(2):6-10.

8. Reed DL, Smith VS, Hammond SL, Rogers, AR, Clayton DH. Genetic analysis of lice supports direct contact between modern and archaic humans. PLOS Biol. 2004;2(11):e340. http://dx.doi.org/10.1371/journal.pbio.0020340

9. Pickrell JK, Patterson N, Barbieri C, Berthold F, Gerlach L, Güldemann T, et al. The genetic prehistory of southern Africa. Nat Commun. 2012;3, Art. 1143. http://dx.doi.org/10.1038/ncomms2140

10. Pickrell JK, Patterson N, Loh P-R, Lipson M, Berger B, Stoneking M, et al. Ancient west Eurasian ancestry in southern and eastern Africa. Proc Natl Acad Sci USA. 2014;111(7):2632-2637. http://dx.doi.org/10.1073/ pnas. 1313787111

11. Schlebusch, C, Lombard $M$, Soodyall H. mtDNA control region variation affirms diversity and deep sub-structure in populations from southern Africa. BMC Evol Biol. 2013;13:56-76. http://dx.doi.org/10.1186/1471-2148-13-56

12. Breton $G$, Schlebusch CM, Lombard M, Soodyall H, Jakobsson M. Lactase persistence alleles reveal partial East African ancestry of southern African Khoe pastoralists. Curr Biol. 2014;24:852-858. http://dx.doi.org/10.1016/j. cub.2014.02.041 